\title{
INHIBITION OF IRE1 MODIFIES THE HYPOXIC REGULATION OF GADD FAMILY GENE EXPRESSIONS IN U87 GLIOMA CELLS
}

\author{
O. H. MINCHENKO', I. V. KRYVDIUK', O. O. RIABOVOL ${ }^{1}$, \\ D. O. MINCHENKO ${ }^{1,2}$, S. V. DANILOVSKYI , O. O. RATUSHNA \\ ${ }^{1}$ Palladin Institute of Biochemistry, National Academy of Sciences of Ukraine, Kyiv; \\ e-mail: ominchenko@yahoo.com; \\ ${ }^{2}$ Bohomolets National Medical University, Kyiv, Ukraine
}

\begin{abstract}
We have studied hypoxic regulation of the expression of genes encoded GADD (growth arrest and DNA damage) family proteins in U87 glioma cells in relation to inhibition of IRE1 (inositol requiring enzyme-1), which controls cell proliferation and tumor growth as a central mediator of endoplasmic reticulum stress. We have shown that hypoxia up-regulates the expression of GADD34, GADD45A, GADD45B, and GADD153 genes, which are related to cell proliferation and apoptosis, in control (transfected by empty vector) glioma cells in gene specific manner. At the same time, the expression level of EIF2AK1 (eukaryotic translation initiation factor 2-alpha kinase 1) and AIFM1 (apoptosis inducing factor, mitochondria associated 1) genes in these cells is down-regulated upon hypoxic condition. It was also shown that inhibition of IRE1 signaling enzyme function in U87 glioma cells enhances the effect of hypoxia on these genes expression, except EIF2AKI and AIFM1 genes. Furthermore, the expression of all studied genes in IRE1 knockdown cells is significantly decreased upon normoxic condition, except GADD45B gene, which expression level is strongly up-regulated. Therefore, the expression level of genes encoding GADD34, GADD45A, GADD45B, GADD153, EIF2AK1, and AIFM1 is affected by hypoxia and by inhibition of IRE1-mediated endoplasmic reticulum stress signaling in gene specific manner and correlates with suppression of glioma cell proliferation upon inhibition of the IRE1 enzyme function.
\end{abstract}

Key words: hypoxia, mRNA expression, GADD34, GADD45A, GADD45B, GADD153, EIF2AK1, AIFM1, IRE1 inhibition, glioma cells.

$\mathrm{E}$ ndoplasmic reticulum stress and hypoxia are necessary components of malignant tumors growth [1-3]. Moreover, the endoplasmic reticulum stress response IRE1/ERN1 (inositol requiring enzyme 1 /from endoplasmic reticulum to nucleus signaling 1) signalling pathway is linked to the apoptosis and cell death processes and suppression of its function significantly decreases the glioma growth [4, 5]. Malignant gliomas are highly aggressive tumors and are characterized by marked angiogenesis, extensive tumor cell invasion into the normal brain parenchyma and to date there is no efficient treatment available. The very poor prognosis and the moderate efficacy of conventional clinical approaches therefore underline the need for new therapeutic strategies.

Hypoxia is associated to glioma development and locally induces an adaptive response which confers to tumor cells an enhanced survival and a more agressive behaviour. A better knowledge of tumor responses to hypoxia is required to elaborate therapeutical strategies of cell sensibilization, based on the blockade of survival mechanisms [6, 7]. The endoplasmic reticulum is a key organelle in the cellular response to hypoxia, ischemia, and some chemicals which activate a complex set of signaling pathways named the unfolded protein response. This adaptive response is activated upon the accumulation of misfolded proteins in the endoplasmic reticulum and is mediated by three endoplasmic reticulum-resident sensors named IRE1, PERK (PRK-like endoplasmic reticulum kinase), and ATF6 (activating transcription factor 6); however, IRE is the dominant sensor of the unfolded protein response to the accumulation of misfolded proteins and represents a key regulator of life and death processes $[1,8,9]$. Misfolded proteins in the endoplasmic reticulum lumen activate two distinct catalytic domains of IRE1, which display serine/threonine trans-autophosphorylation and endoribonuclease activities, respectively. IRE1-asso- 
ciated endoribonuclease activity is involved in the degradation of a specific subset of mRNA and also initiates the cytosolic splicing of the pre-XBP1 (Xbox binding protein 1) mRNA whose mature transcript encodes a transcription factor that stimulates the expression of unfolded protein response specific genes $[2,10]$.

Growth arrest and DNA damage (GADD34) represents the stress-inducible regulatory subunit 15A of protein phosphatase 1 (PPP1R15A), which dephosphorylates the translation initiation factor eIF2A/EIF2S1, thereby reversing the shut-off of protein synthesis initiated by stress-inducible kinases and facilitating recovery of cells from stress [11, 12]. In the integrated stress response, phosphorylation of eIF $2 \alpha$ (eIF $2 \alpha-\mathrm{P})$ reduces protein synthesis to conserve resources and facilitate preferential translation of transcripts that promote stress adaptation [13]. GADD34 can promote apoptosis by inducing TP53 phosphorylation and other mechanisms [14, 15]. The GADD45A gene is responded to environmental stresses by mediating activation of the p38/JNK pathway and has both tumor suppressor and tumor promoter functions, dependent on the tissue/cell type [16-18]. The GADD45B represents negative growth regulatory protein MyD118, which is involved in the regulation of growth and apoptosis and may block proliferation, survival, and tumorigenesis [19].

The GADD153, also known as DDIT3 (DNA damage-inducible transcript 3 ), is a member of the CCAAT/enhancer-binding protein (C/EBP) family of transcription factors (CHOP) and is activated by endoplasmic reticulum stress in carcinomas [20]. It plays an important role in the regulation of proliferation and promotes endoplasmic reticulum stressmediated apoptosis through affecting the expression of TNFRSF10A and TNFRSF10B in human lung cancer cells [21, 22]. Moreover, phosphorylation of EIF2 enhances GADD153/CHOP translation [23].

Eukaryotic translation initiation factor 2-alpha kinase 1 (EIF2AK1), an heme-controlled repressor, acts at the level of translation initiation to downregulate protein synthesis in response to various stress conditions, including endoplasmic reticulum stress through the phosphorylation of EIF2S1, thus preventing its recycling. Moreover, the expression of EIF2AK1 gene is increased in glioblastoma multiforme and controlled by subset of miRNAs and vimentin [24, 25]. Mitochondria associated apoptosis inducing factor 1 (AIFM1) participates in the regulation of apoptosis and tumor growth via activation of
JNK $[26,27]$. Its level in carcinomas is significantly higher than in normal tissues [26].

The aim of this study was investigation the effect of hypoxia on the expression of GADD34, GADD45A, GADD45B, GADD153, and EIF2AK1 genes, which related to cell proliferation and apoptosis, in glioma cells in relation to inhibition of signaling enzyme IRE1.

\section{Materials and Methods}

Cell lines and culture conditions. The glioma cell line U87 was obtained from ATCC (USA) and grown in high glucose (4.5 g/l) Dulbecco's modified Eagle's minimum essential medium (DMEM; Gibco, Invitrogen, USA) supplemented with glutamine (2 mM), 10\% fetal bovine serum (EquitechBio, Inc., USA), penicillin (100 units/ml; Gibco) and streptomycin $\left(0.1 \mathrm{mg} / \mathrm{ml}\right.$; Gibco) at $37{ }^{\circ} \mathrm{C}$ in a $5 \%$ $\mathrm{CO}_{2}$ incubator. In this work we used two sublines of this glioma cell line. One subline was obtained by selection of stable transfected clones with overexpression of vector (pcDNA3.1), which was used for creation of dominant-negative constructs (dnIRE1). This untreated subline of glioma cells (control glioma cells) was used as control 1 in the study of effects of hypoxia on the expression level of GADD34, GADD45A, GADD45B, GADD153, EIF2AK1, and $A I F M 1$ genes. Second subline was obtained by selection of stable transfected clones with overexpression of dnIRE1 and has suppressed both protein kinase and endoribonuclease activities of this bifunctional sensing and signaling enzyme of endoplasmic reticulum stress. The expression level of studied genes in these cells was compared with cells, transfected by vector (control 1), but subline which overexpress dnIRE1 was also used as control 2 for investigation the effect of hypoxia condition on the expression level of these genes under blockade IRE1 function. Clones were received by selection at $0.8 \mathrm{mg} / \mathrm{ml}$ geneticin (G418) and grown in the presence of this antibiotic at lower concentration $(0.4 \mathrm{mg} / \mathrm{ml})$.

Hypoxic condition was created in special incubator with $3 \%$ oxygen and $5 \%$ carbon dioxide levels; culture plates with complete DMEM were exposed to these conditions for $16 \mathrm{hrs}$.

The suppression level of IRE1 both enzymatic activity in glioma cells that overexpress a dominantnegative construct of inositol requiring enzyme-1 was estimated by determining the expression level of XBP1 alternative splice variant (XBP1s), a key transcription factor in IRE1 signaling, using cells treated 
by tunicamycin $(0.01 \mathrm{mg} / \mathrm{ml}$ during $2 \mathrm{~h})$, which specifically induces the unfolded protein response and is generally used as an experimental tool for this aim. It represents a mixture of homologous nucleoside antibiotics that inhibits the N-linked glycosylation and causes cell cycle arrest in G1 phase. As shown in Fig. 1, treatment of control (transfected by vector) glioma U87 cells with tunicamycin leads to the formation of an alternative splice variant of XBP1 while in cells transfected by dnIRE1 the alternative splicing of XBP1 is completely blocked.

Moreover, the proliferation rate of glioma cells with mutated IRE1 is decreased in 2 fold [28]. Thus, the blockade of both kinase and endoribonuclease activity of signaling enzyme IRE1 has significant effect on proliferation rate of glioma cells.

RNA isolation. Total RNA was extracted from glioma cells as previously described [29]. The RNA pellets were washed with $75 \%$ ethanol and dissolved in nuclease-free water. For additional purification RNA samples were re-precipitated with $95 \%$ ethanol and re-dissolved again in nuclease-free water. RNA concentration and spectral characteristics were measured using NanoDrop Spectrophotometer ND1000 (PEQLAB, Biotechnologie GmbH).

Reverse transcription and quantitative $P C R$ analysis. QuaniTect Reverse Transcription Kit (QIAGEN, Hilden, Germany) was used for cDNA synthesis as described previously [28]. The expression level of GADD34, GADD45A, GADD45B, GADD153, and EIF2AK1 mRNA were measured in glioma cell line U87 and its subline (clone 1C5) by real-time quantitative polymerase chain reaction using "Mx 3000P QPCR" (Stratagene, USA) or "7900 HT Fast Real-Time PCR System" (Applied Biosystems) and Absolute qPCR SYBRGreen Mix (Thermo Fisher Scientific, ABgene House, Epsom, Surrey, UK). Polymerase chain reaction was performed in triplicate.

For amplification of the growth arrest and DNA-damage-inducible 34 (GADD34) also known as regulatory subunit $15 \mathrm{~A}$ of protein phosphatase 1 (PPP1R15A) cDNA we used next primers: forward 5'-GAATCAAGCCACGGAGGATA-3' and reverse 5'-CAGGGAGGACACTCAGCTTC-3'. The nucleotide sequences of these primers correspond to sequences 953-972 and 1261-1242 of human GADD34 cDNA (GenBank accession number NM_014330). The size of amplified fragment is $309 \mathrm{bp}$.

The amplification of cDNA of the growth arrest and DNA-damage-inducible 45A (GADD45A)

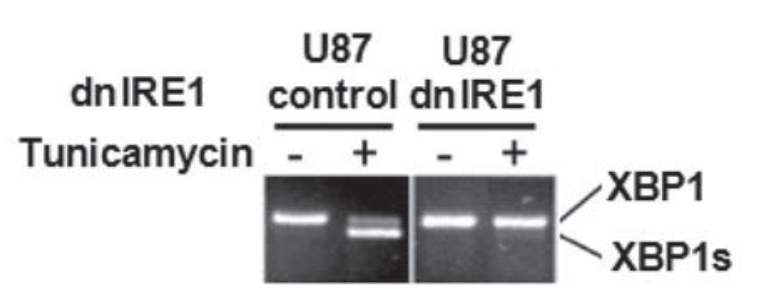

Fig. 1. Effect of tunicamycin $(0.01 \mathrm{mg} / \mathrm{ml}-2 \mathrm{~h})$ on the $m R N A$ level of transcription factor XBPI and its alternative splice variant (XBP1s) in U87 glioma cells stable transfected with empty vector (U87 control) and dnIRE1 (U87 dnIRE1) measured by reverse-transcriptase-mediated PCR analysis

also known as DNA damage-inducible transcript-1 (DDIT1) was performed using forward primer (5'CAGCTTCGGAACAAGAGACC $-3^{\prime}$ ) and reverse primer (5'-GTCCGATGATTCCTGCTGAT-3'). These oligonucleotides correspond to sequences $364-383$ and 656-637 of human GADD45A cDNA (GenBank accession number NM_002392). The size of amplified fragment is $293 \mathrm{bp}$.

For amplification of the growth arrest and DNA-damage-inducible 153 (GADD153) also known as DNA damage-inducible transcript-3 (DDIT3) and CCAAT/enhancer-binding protein homologous protein (CHOP) cDNA we used forward $5^{\prime}-$ AGCCAAAATCAGAGCTGGAA- $3^{\prime}$ and reverse 5'-TGTGACCTCTGCTGGTTCTG-3' primers. The nucleotide sequences of these primers correspond to sequences $128-147$ and 462-443 of human GADD153 cDNA (GenBank accession number NM_004083). The size of amplified fragment is 229 bp.

The amplification of the growth arrest and DNA-damage-inducible 45B (GADD45B) also known as Negative Growth Regulatory Protein MyD118 (MYD118) cDNA for real time RCR analysis was performed using two oligonucleotides primers: forward - 5'-ACGAGGACGACGACAGAGAT-3' and reverse - 5'-TCCCGGCAAAAACAAATAAG-3'. The nucleotide sequences of these primers correspond to sequences 503-522 and 764-745 of human GADD45B cDNA (GenBank accession number NM_001924). The size of amplified fragment is $262 \mathrm{bp}$.

For amplification of the eukaryotic translation initiation factor 2-alpha kinase 1 (EIF2AK1) also known as heme-controlled repressor or hemeregulated inhibitor (HRI) cDNA we used forward 5'-AGACAGAGGCACAGTACCAC-3' and reverse 
5'-TTACTTGCTGATCAGGGCCA-3' primers. The nucleotide sequences of these primers correspond to sequences 1258-1277 and 1518-1499 of human GADD153 cDNA (GenBank accession number NM_014413). The size of amplified fragment is $261 \mathrm{bp}$.

The amplification of the apoptosis inducing mitochondria associated factor 1 (AIFM1) cDNA into real time RCR analysis was performed using two oligonucleotides primers: forward $-5^{\prime}-\mathrm{CC}$ CAATGTTGAGTTGGCCAA- ${ }^{\prime}$ ' and reverse $-5^{\prime}-$ AGCGTGATCATGGTGCTCTA-3'. The nucleotide sequences of these primers correspond to sequences 1435-1454 and 1605-1586 of human AIFM1 cDNA (GenBank accession number NM_004208). The size of amplified fragment is $171 \mathrm{bp}$.

For amplification of beta-actin (ACTB) cDNA was used forward - 5'-GGACTTCGAGCAAGAGATGG-3' and reverse - 5'-AGCACTGTGTTGGCGTACAG-3' primers. These primers nucleotide sequences correspond to 747-766 and 980-961 of human ACTB cDNA (GenBank accession number NM_001101). The size of amplified fragment is $234 \mathrm{bp}$. The expression of beta-actin mRNA was used as control of analyzed RNA quantity. The primers were received from "Sigma-Aldrich" (St. Louis, MO, USA).

Quality of amplification products were analyzed by melting curves and by agarose electrophoresis. An analysis of quantitative PCR was performed using special computer program "Differential expression calculator". The values of GADD34, GADD45A, GADD45B, GADD153, EIF2AK1 and AIFM1 mRNA expressions were normalized to the expression of beta-actin mRNA and represented as percent of control 1 (100\%).

Statistical analysis. All values are expressed as mean \pm SEM from triplicate measurements performed in 4 independent experiments. Statistical analysis was performed according to Student's $t$-test using Excel program as described previously [30].

\section{Results and Discussion}

We have studied the effect of hypoxia on the expression of GADD34, GADD45A, GADD45B, GADD153, and EIF2AK1 genes in two sublines of U87 glioma cells in relation to inhibition of IRE1 signaling enzyme, which is a major component of endoplasmic reticulum stress. It was shown that in control glioma cells (transfected by empty vector) hypoxia strongly up-regulates the expression of GADD34/PPPIR15A gene (+278\%; Fig. 2).
Furthermore, the expression of this gene is also increased by hypoxia $(+339 \%)$ in cells without functional activity of signaling enzyme IRE1, being slightly more significant than in control glioma cells. As shown in Fig. 2, inhibition of IRE1 enzyme function in U87 glioma cells by dnIRE1 leads to significant down-regulation of GADD34 gene expression $(-64 \%)$. Thus, hypoxia and inhibition of IRE1 have opposite effects on the expression of GADD34/PPP1R15A gene in U87 glioma cells.

As shown in Fig. 3, the expression level of GADD45A gene is increased in control glioma cells treated by hypoxia $(+26 \%)$, but in glioma cells with suppressed activity of IRE1 signaling enzyme effect of hypoxia on the expression level of this gene was more significant $(+85 \%)$. Furthermore, the expression of this gene is decreased (-54\%) in cells without functional activity of signaling enzyme IRE1 as compared to control glioma cells (Fig. 3). Thus, hypoxia and inhibition of IRE1 have also opposite

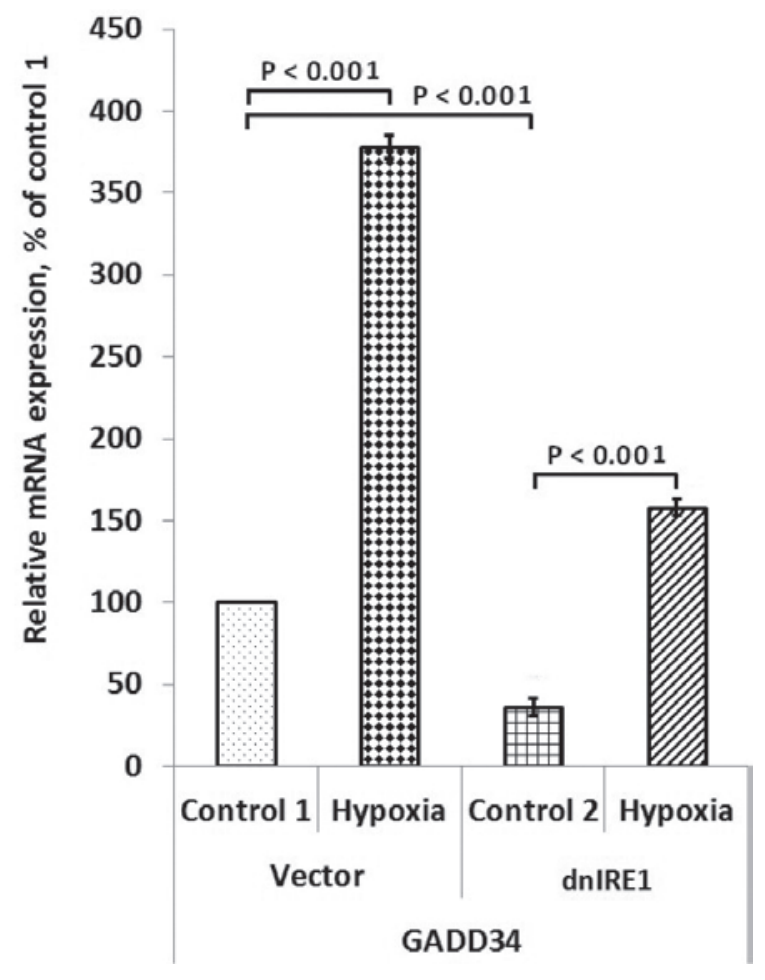

Fig. 2. Effect of hypoxia (3\% oxygen $-16 \mathrm{~h})$ on the expression level of GADD34/PPP1R15A mRNA in control U87 glioma cells stable transfected with vector (Vector) and cells without signaling enzyme IRE1 function (dnIRE1) measured by qPCR. Values of GADD34 mRNA expressions were normalized to beta-actin $\mathrm{mRNA}$ expression and represented as percent of control 1 (100\%); $n=4$ 


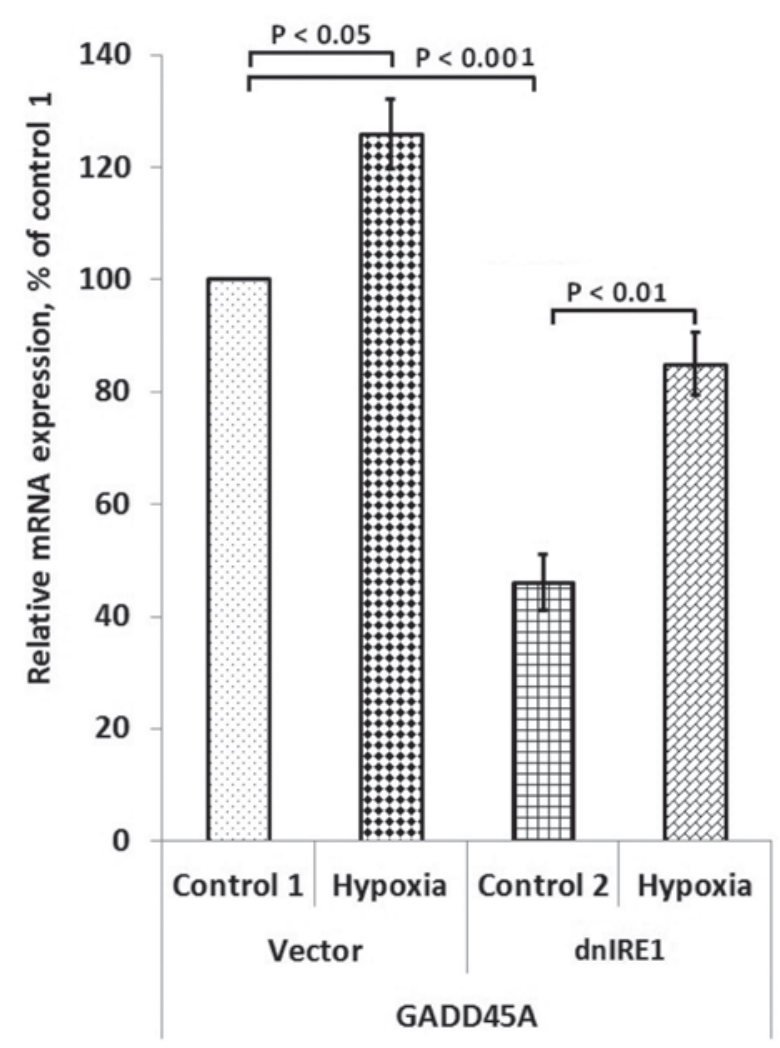

Fig. 3. Effect of hypoxia (3\% oxygen - 16 h) on the expression level of GADD45A/DDIT1 mRNA in control U87 glioma cells stable transfected with vector (Vector) and cells without signaling enzyme IRE1 function (dnIRE1) measured by qPCR. Values of GADD45A mRNA expressions were normalized to beta-actin $m R N A$ expression and represented as percent of control 1 (100\%); $n=4$

effects on the expression of GADD45A/DDIT1 gene in U87 glioma cells.

It was also shown that in glioma cells transfected by empty vector (control cells) hypoxia strongly up-regulates the expression of GADD45B/MYD118 gene $(+233 \%)$, but in cells, where signaling enzyme IRE1 activity was inhibited by dnIRE1, effect of hypoxia on the expression of this gene was significantly lesser (+44\%) than in control glioma cells (Fig 4). As also shown in this figure, inhibition of IRE1 enzyme function in U87 glioma cells by dnIRE1 leads to significant up-regulation of GADD $45 B$ gene expression $(+78 \%)$ as compared to control glioma cells. Thus, both hypoxia and inhibition of IRE1 significantly increase the expression of $G A D D 45 B$ gene in U87 glioma cells.

We also investigated the effect of hypoxia on the expression of GADD153/CHOP gene in two sub-

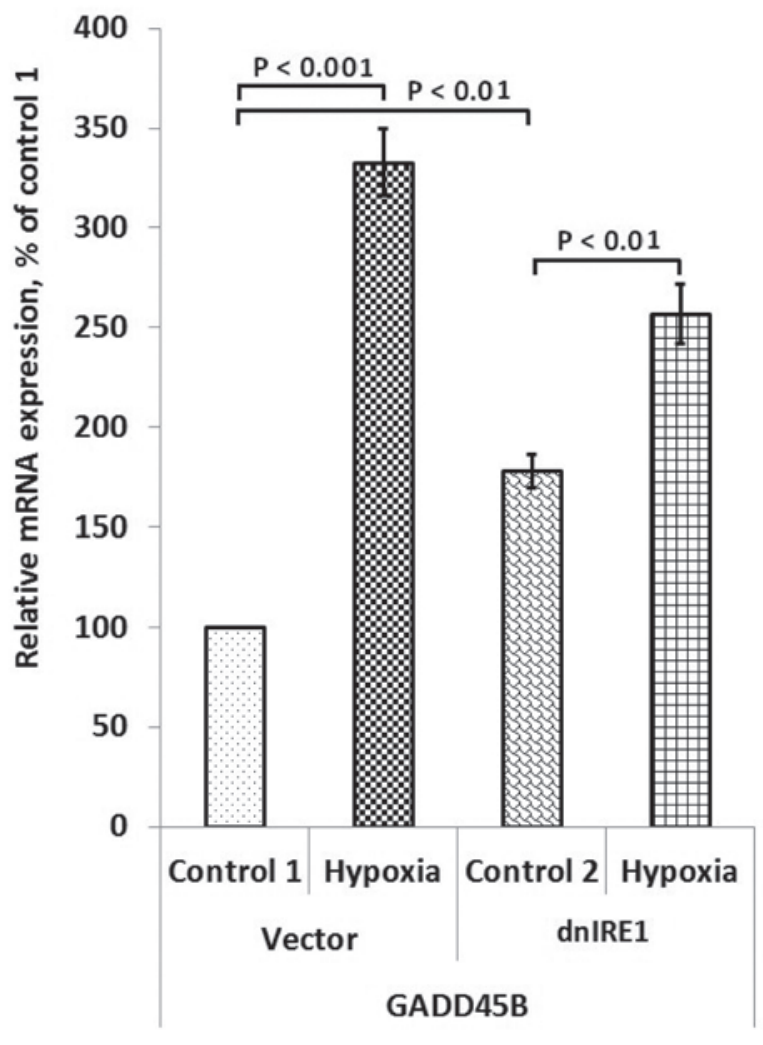

Fig. 4. Effect of hypoxia (3\% oxygen -16 h) on the expression level of GADD45B/MYD118 mRNA in control U87 glioma cells stable transfected with vector (Vector) and cells without function of signaling enzyme IRE1 (dnIRE1) measured by qPCR. Values of GADD $45 B$ mRNA expressions were normalized to beta-actin $m R N A$ expression and represented as percent of control 1 (100\%); $n=4$

lines of U87 glioma cells in relation to inhibition of IRE1 signaling enzyme. As shown in Fig. 5, hypoxia strongly increases the expression level of GADD153 gene (+91\%) in control glioma cells (transfected by empty vector). Moreover, the expression of this gene in cells without functional activity of signaling enzyme IRE1 is also increased by hypoxia $(+236 \%)$, being more significant than in control glioma cells $(+91 \%)$. We have also shown that in normoxic condition inhibition of IRE1 enzyme function by dnIRE1 leads to significant down-regulation of GADD135 gene expression (-89\%) in U87 glioma cells (Fig. 5). Thus, hypoxia and inhibition of IRE1 have opposite effects on the expression of GADD135/CHOP gene in U87 glioma cells.

At the same time, the expression level of EIF $2 A K 1$ gene is strongly $(-59 \%)$ down-regulated by hypoxia in control U87 glioma cells as com- 


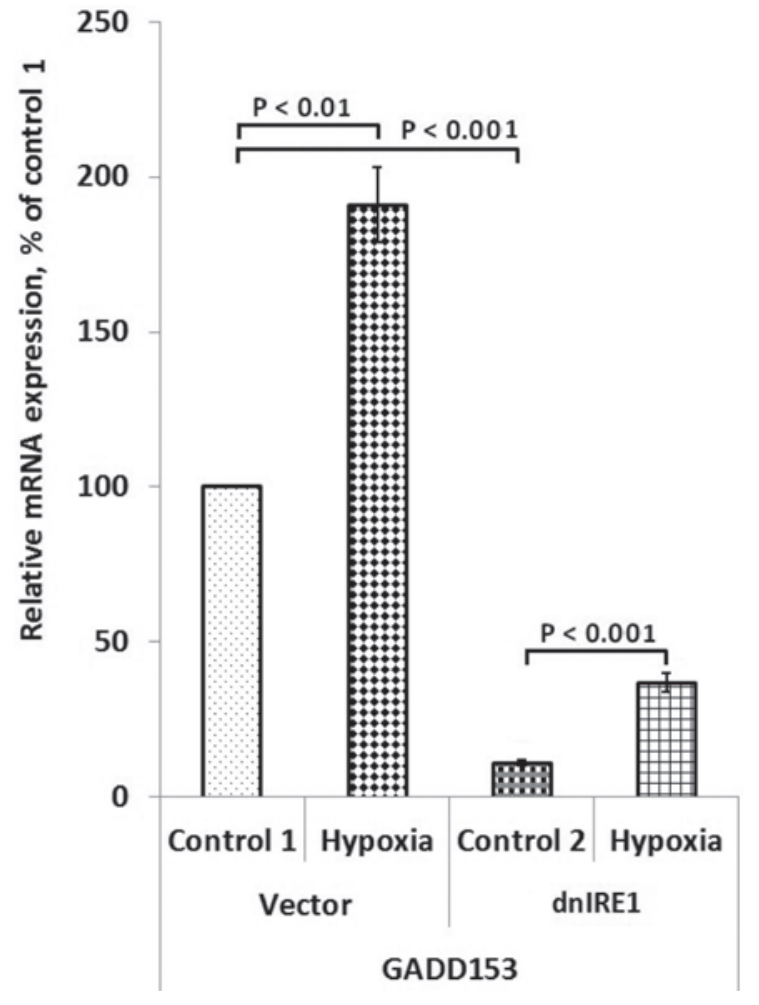

Fig. 5. Effect of hypoxia (3\% oxygen -16 h) on the expression level of GADD153/DDIT3/CHOP mRNA in control U87 glioma cells stable transfected with vector (Vector) and cells without function of signaling enzyme IRE1 (dnIRE1) measured by $q P C R$. Values of GADD153 $m R N A$ expressions were normalized to $\beta$-actin $m R N A$ expression and represented as percent of control 1 (100\%); $n=4$

pared to control 1 (Fig. 6). Moreover, hypoxia also down-regulates the expression of this gene $(-51 \%)$ in cells with IRE1 knockdown, being slightly more significant in control glioma cells. Investigation of EIF2AK1 gene expression in U87 glioma cells shown that inhibition of IRE1 signaling enzyme function by dnIRE1 leads to significant down-regulation $(-51 \%)$ of this gene expression in normoxic condition (Fig. 6). Thus, hypoxia and inhibition of IRE1 have unidirectional and approximately similar effects on the expression of EIF $2 A K 1$ gene in U87 glioma cells.

The expression level of apoptosis inducing mitochondria associated factor 1 (AIFMI) gene is significantly $(-45 \%)$ down-regulated by hypoxia in control glioma cells as compared to control 1 cells (Fig. 7). Furthermore, hypoxia also decreases the expression level of this gene (-34\%) in cells with inhibited IRE1 signaling enzyme function. Therefore, inhibition of IRE1 slightly decreases the effect of hypoxia on the expression of AIFM1 gene in U87 glioma cells. Moreover, investigation of AIFM1 gene expression shown that inhibition of IRE1 signaling enzyme function in glioma cells by dnIRE1 leads to significant down-regulation $(-56 \%)$ of this gene expression in normoxic condition (Fig. 7). Thus, hypoxia and inhibition of IRE1 have unidirectional and approximately similar effects on the expression of AIFM1 gene in U87 glioma cells.

In this study we have shown that hypoxia strongly affects the expression level of most studied growth arrest and DNA damage gene family as well as EIF2AK1 and AIFM1 genes in U87 glioma cells and that inhibition of IRE1 signaling enzyme function preferentially modifies the effect of hypoxia on the expression level of these genes in gene specific manner like many other previously studied genes [28, 31-33]. Therefore, hypoxia increases the ex-

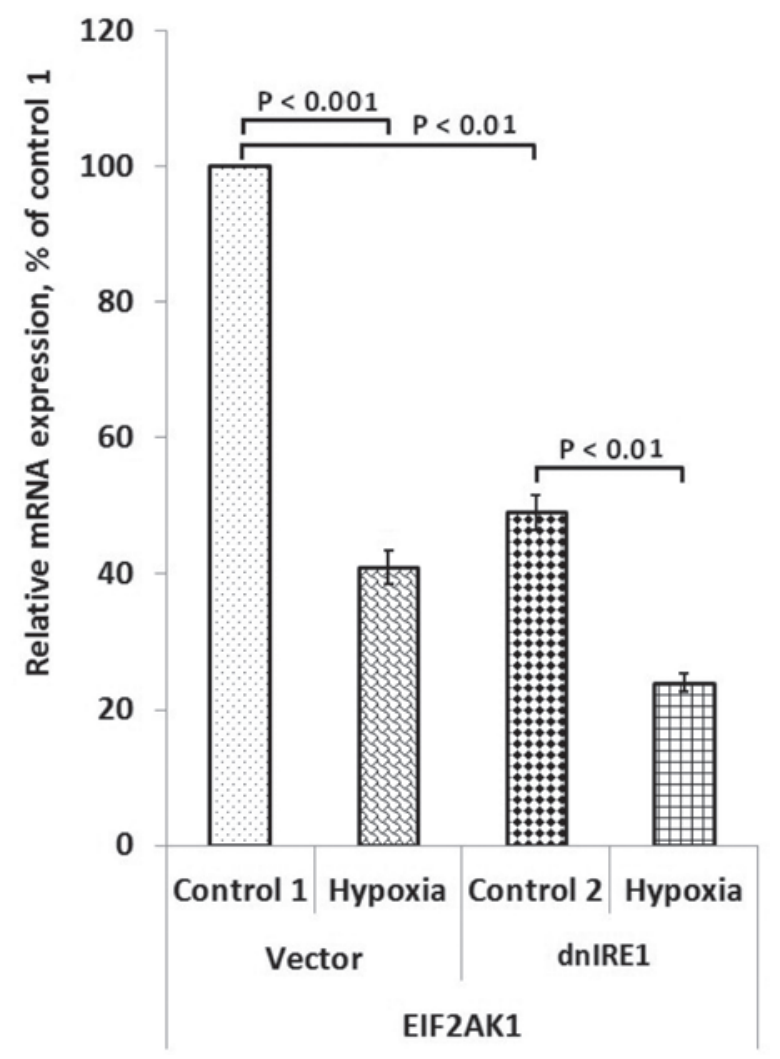

Fig. 6. Effect of hypoxia (3\% oxygen $-16 \mathrm{~h})$ on the expression level of EIF2AK1/HRI mRNA in control U87 glioma cells stable transfected with vector (Vector) and cells without function of signaling enzyme IRE1 (dnIRE1) measured by qPCR. Values of EIF2AK1 mRNA expressions were normalized to $\beta$-actin $m R N A$ expression and represented as percent of control $1(100 \%) ; n=4$ 


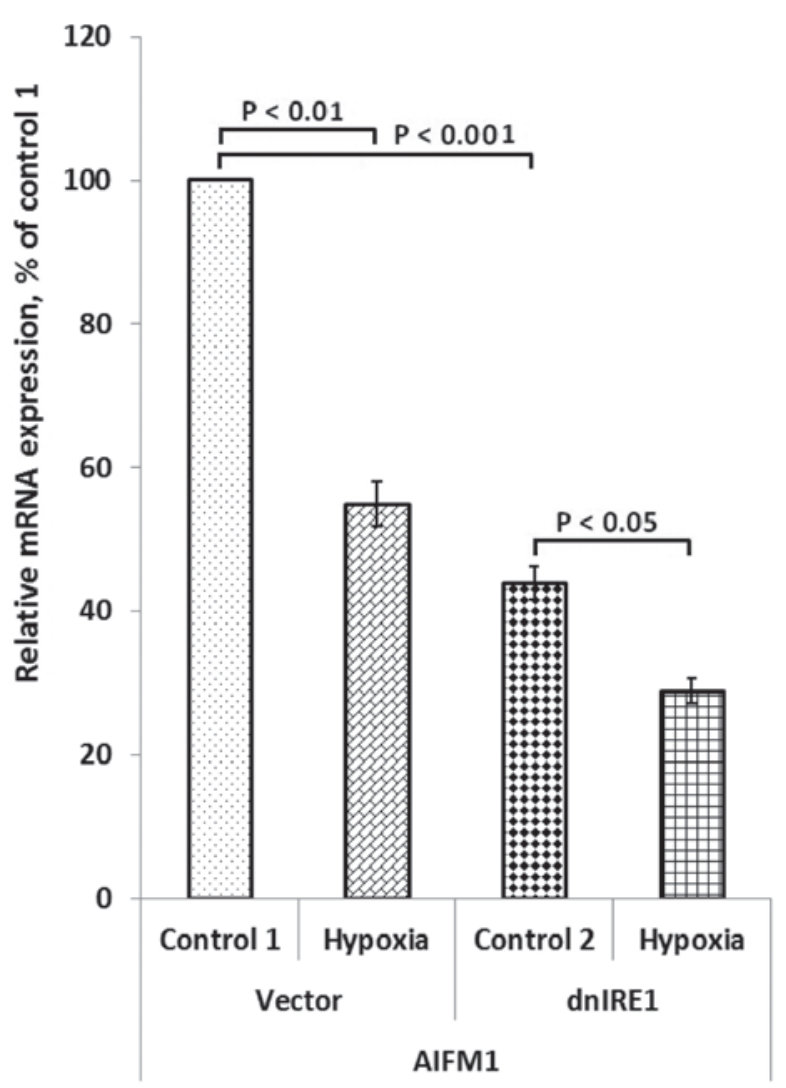

Fig. 7. Effect of hypoxia (3\% oxygen - 16 h) on the expression level of AIFM1 mRNA in control U87 glioma cells stable transfected with empty vector (Vector) and cells without function of signaling enzyme IRE1 (dnIRE1) measured by qPCR. Values of AIFMI mRNA expressions were normalized to betaactin $m R N A$ expression and represented as percent of control 1 (100\%); $n=4$

pression of GADD33, GADD45A, GADD45B, and GADD153 genes but decreased EIF $2 A K 1$ and AIFM1 genes. Most of these genes (GADD33, GADD45A, and $G A D D 153$ ) have pro-proliferative properties and they enhanced expression upon hypoxic condition correlates with data that hypoxia is associated to tumor progression [6, 7, 34-36]. Moreover, inhibition of IRE1 signaling enzyme function suppresses glioma cell proliferation and growth $[4,37]$ and significantly decreases the expression level of GADD33, GADD45A, and GADD153 genes. At the same time, inhibition of IRE1 signaling enzyme slightly enhances the hypoxic regulation of the expression of these gene expressions in glioma cells. It is possible that hypoxic regulation of GADD33, GADD45A, and GADD153 genes through multiple signaling pathways and IRE1 plays ancillary role. Thus, our results agree with data $[4,6,34]$ that the suppression of IRE1 signaling enzyme function significantly decreases the glioma cell proliferation and that reduced level of GADD33, GADD45A, and GADD153 genes expression can contribute to suppression of proliferation and to regulation of cell death processes.

In this study we also studied the expression level of $G A D D 45 B$ gene, which encodes a negative growth regulatory protein MyD118, involved in the regulation of growth and apoptosis and may block proliferation, survival, and tumorigenesis [19]. Our results argue with this data because we have shown that inhibition of IRE1 signaling enzyme significantly up-regulates this gene expression. At the same time, hypoxia strongly enhances the expression of $G A D D 45 B$ gene in control glioma cells but biological significance of this gene expression up-regulation requires further investigation.

Results of this investigation clearly demonstrated that the expression of gene encoding eukaryotic translation initiation factor 2-alpha kinase 1, which acts at the level of translation initiation to downregulate protein synthesis in response to endoplasmic reticulum stress through the phosphorylation of EIF2S1, is down-regulated in U87 glioma cells without IRE1 signaling enzyme function. We have also shown that inhibition of IRE1 leads to strong suppression of the expression of AIFM1 gene. This data correlates with suppression of glioma growth from cells without functional activity of signalling enzyme IRE1 and with increased expression of EIF2AK1 and AIFM1 genes in glioblastoma multiforme and other tumors $[4,24,26,27]$. At the same time, the expression of EIF2AK1 and AIFM1 genes is also down-regulated by hypoxia in both control and IRE1 knockdown glioma cells; however, it is not clear yet the functional significance of these changes in EIF2AK1 and AIFM1 gene expressions and warrants further study.

Therefore, the expression level of genes encoding GADD34, GADD45A, and GADD153 is up-regulated by hypoxia in gene specific manner. At the same time, inhibition of the IRE1 enzyme function down-regulates the expression level of preferentially pro-proliferative genes (GADD34, GADD45A, $G A D D 153$, and $E I F 2 A K 1$ ) and up-regulates $G A D$ $D 45 B$ gene, which encodes a negative growth regulatory protein. Thus, our results correlate with suppression of glioma cell proliferation upon inhibition of IRE1-mediated endoplasmic reticulum stress signaling. 


\section{ПРИГНІЧЕННЯ IRE1 МОДИФІКУС ГІПОКСИЧНУ РЕГУЛЯЩІЮ ЕКСПРЕСІї ГЕНІВ РОДИНИ GADD У КЛІТИНАХ ГЛІОМИ ЛІНІЇ U87}

О. Г. Мінченко, І. В. Кривдюк', О. О. Рябовол ${ }^{1}$, Д. О. Мінченко, С. В. Даніловськийㄱ, О. О. Ратушна

${ }^{1}$ Інститут біохімії ім. О.В. Палладіна НАН України, Київ; e-mail: ominchenko@yahoo.com; ${ }^{2}$ Національний медичний університет ім. О. О. Богомольця, Київ, Україна

Вивчали гіпоксичну регуляцію експресії генів, що кодують родину протеїнів GADD (growth arrest and DNA damage), у клітинах гліоми лінії U87 за пригнічення IRE1 (inositol requiring enzyme-1), який $\epsilon$ центральним медіатором стресу ендоплазматичного ретикулума і контролює процеси проліферації та росту пухлин. Показано, що гіпоксія посилювала експресію генів GADD34, GADD45A, $G A D D 45 B$ та $G A D D 153$, функція яких пов'язана 3 проліферацією та апоптозом клітин, у контрольних (трансфікованих вектором без вставки) клітинах гліоми геноспецифічно. Водночас, рівень експресії генів EIF2AK1 (eukaryotic translation initiation factor 2-alpha kinase 1) та AIFM1 (apoptosis inducing factor, mitochondria associated 1) у цих клітинах знижувався за умов гіпоксії. Встановлено також, що пригнічення функції сигнального ензиму IRE1 у клітинах гліоми лінії U87 посилювало ефект гіпоксії на експресію всіх цих генів за винятком генів EIF2AK1 та AIFM1. Більше того, експресія всіх досліджених генів у клітинах із пригніченим IRE1 істотно знижувалась за умов нормоксії. Таким чином, рівень експресії генів, що кодують GADD34, GADD45A, GADD45B, GADD153, $E I F 2 A K 1$ та $A I F M 1$, змінюється геноспецифічно за гіпоксії та за пригнічення стресу ендоплазматичного ретикулума, опосередкованого IRE1 сигнальним шляхом, і корелює зі зниженням проліферації клітин гліоми у разі пригнічення функції ензиму IRE1.

К л ю ч о в і с ло в а: гіпоксія, експресія мРНК, GADD34, GADD45A, GADD45B, GADD153, EIF2AK1, AIFM1, пригнічення IRE1, клітини гліоми.

\section{УГНЕТЕНИЕ IRE1 МОДИФИЦИРУЕТ ГИПОКСИЧЕСКУЮ РЕГУЛЯЦИЮ ЭКСПРЕССИИ ГЕНОВ СЕМЕЙСТВА GADD В КЛЕТКАХ ГЛИОМЫ ЛИНИИ U87}

О. Г. Минченко ${ }^{1}$ И. В. Крывдюк 1 , О. О. Рябовол ${ }^{1}$, Д. О. Минченко ${ }^{1,2}$, С. В. Даниловский ${ }^{1}$ О. О. Ратушна ${ }^{1}$

${ }^{1}$ Институт биохимии им. А. В. Палладина НАН Украины, Киев; e-mail: ominchenko@yahoo.com;

${ }^{2}$ Национальный медицинский университет им. А. А. Богомольца, Киев, Украина

Исследовали гипоксическую регуляцию экспрессии генов, кодирующих семейство протеинов GADD (growth arrest and DNA damage), в клетках глиомы линии U87 при угнетении IRE1 (inositol requiring enzyme-1), который является центральным медиатором стресса эндоплазматического ретикулума и контролирует процессы пролиферации и роста опухолей. Показано, что гипоксия усиливала экспрессию генов $G A D D 34$, $G A D D 45 A, G A D D 45 B$ и $G A D D 153$, функция которых связана с пролиферацией и апоптозом клеток, в контрольных (трансфецированных вектором без вставки) клетках глиомы геноспецифически. В то же время, уровень экспрессии генов EIF2AK1 (eukaryotic translation initiation factor 2-alpha kinase 1) и AIFMI (apoptosis inducing factor, mitochondria associated 1) в этих клетках снижался при гипоксии. Установлено также, что угнетение функции сигнального энзима IRE1 в клетках глиомы линии U87 усиливало эффект гипоксии на экспрессию всех этих генов за исключением генов EIF2AK1 и AIFM1. Более того, экспрессия всех исследованных генов существенно снижалась при нормоксии в клетках с угнетенным IRE1. Таким образом, уровень экспрессии генов, кодирующих $G A D D 34$, GADD45A, GADD45B, GADD153, EIF2AK1 и $A I F M 1$, изменяется геноспецифически при гипоксии и при угнетении стресса эндоплазматического ретикулума, опосредованного сигнальным путем IRE1, и коррелирует со снижением роста глиомы при угнетении функции энзима IRE1.

К л ю ч е в ы е с л о ва: гипоксия, экспрессия мРНК, GADD34, GADD45A, GADD45B, GADD153, EIF2AK1, AIFM1, угнетение IRE1, клетки глиомы. 


\section{References}

1. Moenner M, Pluquet $\mathrm{O}$, Bouchecareilh $\mathrm{M}$, Chevet E. Integrated endoplasmic reticulum stress responses in cancer. Cancer Res. 2007; 67(22): 10631-10634.

2. Schröder M. Endoplasmic reticulum stress responses. Cell Mol Life Sci. 2008; 65(6): 862894.

3. Wang S, Kaufman RJ. The impact of the unfolded protein response on human disease. J Cell Biol. 2012; 197(7): 857-867.

4. AufG, Jabouille A, Guérit S, Pineau R, Delugin M, Bouchecareilh M, Magnin N, Favereaux A, Maitre M, Gaiser T, von Deimling A, Czabanka M, Vajkoczy P, Chevet E, Bikfalvi A, Moenner M. Inositol-requiring enzyme lalpha is a key regulator of angiogenesis and invasion in malignant glioma. Proc Natl Acad Sci USA. 2010; 107(35): 15553-15558.

5. Drogat B, Auguste P, Nguyen DT, Bouchecareilh M, Pineau R, Nalbantoglu J, Kaufman RJ, Chevet E, Bikfalvi A, Moenner M. IRE1 signaling is essential for ischemia-induced vascular endothelial growth factor-A expression and contributes to angiogenesis and tumor growth in vivo. Cancer Res. 2007; 67(14): 67006707.

6. Lenihan CR, Taylor CT. The impact of hypoxia on cell death pathways. Biochem Soc Trans. 2013; 41(2): 657-663.

7. Denko NC. Hypoxia, HIF1 and glucose metabolism in the solid tumour. Nat Rev Cancer. 2008; 8(9): 705-713.

8. Hetz C, Chevet E, Harding HP. Targeting the unfolded protein response in disease. Nat Rev Drug Discov. 2013; 12(9): 703-719.

9. Manié SN, Lebeau J, Chevet E. Cellular mechanisms of endoplasmic reticulum stress signaling in health and disease. 3. Orchestrating the unfolded protein response in oncogenesis: an update. Am J Physiol Cell Physiol. 2014; 307(10): C901-C907.

10. Hollien J, Lin JH, Li H, Stevens N, Walter P, Weissman JS. Regulated Irel-dependent decay of messenger RNAs in mammalian cells. J Cell Biol. 2009; 186(3): 323-331.

11. Tampakakis E, Tabit CE, Holbrook M, Linder EA, Berk BD, Frame AA, Bretón-Romero R, Fetterman JL, Gokce N, Vita JA, Hamburg NM. Intravenous lipid infusion induces endoplasmic reticulum stress in endothelial cells and blood mononuclear cells of healthy adults. $J$ Am Heart Assoc. 2016; 5(1): e002574.

12. Choy MS, YusoffP, Lee IC, Newton JC, Goh CW, Page R, Shenolikar S, Peti W. Structural and Functional Analysis of the GADD34:PP1 eIF2 $\alpha$ Phosphatase. Cell Rep. 2015; 11(12): 1885-1891.

13. Young SK, Willy JA, Wu C, Sachs MS, Wek RC. Ribosome Reinitiation Directs Gene-specific Translation and Regulates the Integrated Stress Response. J Biol Chem. 2015; 290(47): 2825728271.

14. Lee SK, Kim YS. Phosphorylation of eIF $2 \alpha$ attenuates statin-induced apoptosis by inhibiting the stabilization and translocation of $\mathrm{p} 53$ to the mitochondria. Int J Oncol. 2013; 42(3): 810-816.

15. Liu L, Ito S, Nishio N, Sun Y, Chen N, Tanaka Y, Isobe K. GADD34 facilitates cell death resulting from proteasome inhibition. Anticancer Res. 2015; 35(10): 5317-5324.

16. Hoffman B, Liebermann DA. Gadd45 in modulation of solid tumors and leukemia. $A d v$ Exp Med Biol. 2013; 793: 21-33.

17. Salvador JM, Brown-Clay JD, Fornace AJ Jr. Gadd45 in stress signaling, cell cycle control, and apoptosis. Adv Exp Med Biol. 2013;793:1-19.

18. Zhang XY, Xun-Qu, Wang CQ, Liu GX, Zhou CJ, Wang ZG. Expression of growth arrest and DNA damage inducible 45a in human oral squamous cell carcinoma is associated with tumor progression and clinical outcome. J Cancer Res Ther. 2014; 10(Suppl): C108-C113.

19. Michaelis KA, Knox AJ, Xu M, KiseljakVassiliades K, Edwards MG, Geraci M, Kleinschmidt-DeMasters BK, Lillehei KO, Wierman ME. Identification of growth arrest and DNA-damage-inducible gene beta (GADD45beta) as a novel tumor suppressor in pituitary gonadotrope tumors. Endocrinology. 2011; 152(10): 3603-3613.

20. Bifulco G, Miele C, Di Jeso B, Beguinot F, Nappi C, Di Carlo C, Capuozzo S, Terrazzano G, Insabato L, Ulianich L. Endoplasmic reticulum stress is activated in endometrial adenocarcinoma. Gynecol Oncol. 2012; 125(1): 220225.

21. Li T, Su L, Lei Y, Liu X, Zhang Y, Liu X. DDIT3 and KAT2A proteins regulate TNFRSF10A and TNFRSF10B expression in endoplasmic reticulum stress-mediated apoptosis in human lung cancer cells. J Biol Chem. 2015; 290(17): 11108-11118. 
22. Tian X, Ye J, Alonso-Basanta M, Hahn SM, Koumenis C, Dorsey JF. Modulation of CCAAT/enhancer binding protein homologous protein (CHOP)-dependent DR5 expression by nelfinavir sensitizes glioblastoma multiforme cells to tumor necrosis factor-related apoptosisinducing ligand (TRAIL). J Biol Chem. 2011; 286(33): 29408-29416.

23. Palam LR, Baird TD, Wek RC. Phosphorylation of eIF2 facilitates ribosomal bypass of an inhibitory upstream ORF to enhance CHOP translation. J Biol Chem. 2011; 286(13): 1093910949.

24. Haapa-Paananen S, Chen P, Hellström K, Kohonen P, Hautaniemi S, Kallioniemi O, Perälä M. Functional profiling of precursor MicroRNAs identifies MicroRNAs essential for glioma proliferation. PLoS One. 2013; 8(4): e60930.

25. Chatterjee S, Panda AC, Berwal SK, Sreejith RK, Ritvika C, Seshadri V, Pal JK. Vimentin is a component of a complex that binds to the 5'UTR of human heme-regulated eIF $2 \alpha$ kinase mRNA and regulates its translation. FEBS Lett. 2013; 587(5): 474-480.

26. Cobanoglu B, Ceyran AB, Simsek M, Şenol S. Immunohistochemical analysis of Bax and AIF in colorectal tumors. Int J Clin Exp Med. 2015; 8(9): 16071-16076.

27. Zhao H, Wang C, Lu B, Zhou Z, Jin Y, Wang Z, Zheng L, Liu K, Luo T, Zhu D, Chi G, Luo Y, Ge P. Pristimerin triggers AIF-dependent programmed necrosis in glioma cells via activation of JNK. Cancer Lett. 2016; 374(1): 136-148.

28. Minchenko DO, Danilovskyi SV, Kryvdiuk IV, Bakalets TV, Lypova NM, Karbovsky LL, Minchenko OH. Inhibition of ERN1 modifies the hypoxic regulation of the expression of TP53related genes in U87 glioma cells. Endoplasm Reticul Stress Dis. 2014; 1(1): 18-26.

29. Minchenko O, Opentanova I, Minchenko D, Ogura T, Esumi H. Hypoxia induces transcription of 6-phosphofructo-2-kinase/fructose2,6-biphosphatase-4 gene via hypoxia-inducible factor-1alpha activation. FEBS Lett. 2004; 576(12): 14-20.

30. Bochkov VN, Philippova M, Oskolkova O, Kadl A, FurnkranzA, Karabeg E, Afonyushkin T, Gruber F, Breuss J, Minchenko A, Mechtcheriakova D, Hohensinner P, Rychli K, Wojta J, Resink T, Erne P, Binder BR, Leitinger N. xidized phospholipids stimulate angiogenesis via autocrine mechanisms, implicating a novel role for lipid oxidation in the evolution of atherosclerotic lesions. Circ Res. 2006; 99(8): 900-908.

31. Minchenko DO, Karbovskyi LL, Danilovskyi SV, Moenner M, Minchenko OH. Effect of hypoxia and glutamine or glucose deprivation on the expression of retinoblastoma and retinoblastomarelated genes in ERN1 knockdown glioma U87 cell line. Am J Mol Biol. 2012; 2(1): 21-31.

32. Minchenko DO, Kharkova AP, Karbovskyi LL, Minchenko $\mathrm{OH}$. Expression of insulin-like growth factor binding protein genes and its hypoxic regulation in U87 glioma cells depends on ERN1 mediated signaling pathway of endoplasmic reticulum stress. Endocr Regul. 2015; 49(2): 73-83.

33. Minchenko OH, Kharkova AP, Minchenko DO, Karbovskyi LL. Effect of hypoxia on the expression of IGFBP6, IGFBP7, NOV, CYR61, WISP1, and WISP2 genes in U87 glioma cells depends on ERN1 mediated signaling pathway of endoplasmic reticulum stress. Ukr Biochem J. 2015; 87(6): 52-63.

34. Koumenis C. ER stress, hypoxia tolerance and tumor progression. Curr Mol Med. 2006; 6(1): 55-69.

35. Bi M, Naczki C, Koritzinsky M, Fels D, Blais J, Hu N, Harding H, Novoa I, Varia M, Raleigh J, Scheuner D, Kaufman RJ, Bell J, Ron D, Wouters BG, Koumenis C. ER stress-regulated translation increases tolerance to extreme hypoxia and promotes tumor growth. EMBO J. 2005; 24(19): 3470-3481.

36. Koumenis C, Naczki C, Koritzinsky M, Rastani S, Diehl A, Sonenberg N, Koromilas A, Wouters BG. Regulation of protein synthesis by hypoxia via activation of the endoplasmic reticulum kinase PERK and phosphorylation of the translation initiation factor eIF2alpha. $\mathrm{Mol}$ Cell Biol. 2002; 22(21): 7405-7416.

37. Auf $G$, Jabouille A, Delugin $M$, Guérit $S$, Pineau R, North S, Platonova N, Maitre M, Favereaux A, Vajkoczy P, Seno M, Bikfalvi A, Minchenko D, Minchenko O, Moenner M. High epiregulin expression in human U87 glioma cells relies on IRE1 $\alpha$ and promotes autocrine growth through EGF receptor. BMC Cancer. 2013; 13: 597.

Received 21.03.2016 